\title{
Evaluation of an Online Educational Program for Parents and Caregivers of Children With Food Allergies
}

\author{
Ruiz-Baqués A', Contreras-Porta J2, Marques-Mejías $\mathrm{M}^{2}$, Cárdenas Rebollo JM³ , Capel Torres F4, \\ Ariño Pla MN ${ }^{5}$, Zorrozua Santisteban $A^{6}$, Chivato $T^{7}$ \\ 'Mejo Digital Health, Barcelona, Spain \\ ${ }^{2}$ Department of Allergy, Hospital La Paz Institute for Health Research (IdiPAZ), Madrid, Spain \\ ${ }^{3}$ Department of Applied Mathematics and Statistics, CEU San Pablo University, Madrid, Spain \\ ${ }^{4}$ AEPNAA, Asociación Española de Personas con Alergia a Alimentos y Látex, Madrid, Spain \\ ${ }^{5}$ Immunitas Vera, Asociación Catalana de Alergia Alimentarias, Tarragona, Spain \\ ${ }^{6}$ Elikalte, Asociación Vasca de Alergias alimentarias, Bilbao, Spain \\ 'Decanato, Facultad de Medicina, Facultad de Medicina, Universidad CEU San Pablo, Grupo Hospitales HM, Spain
}

J Investig Allergol Clin Immunol 2018; Vol. 28(1): 37-41

doi: 10.18176/jiaci.0214

\begin{abstract}
Background: The increasing prevalence of food allergy affects both patients and their families.

Objective: The aim of this study was to evaluate the impact of an online educational program designed for parents and caregivers of children with food allergies. The program was developed by a multidisciplinary group comprising health care professionals, researchers, and expert patients under the participatory medicine model.

Material and Methods: Participants took a 2-week online educational program covering major topics in food allergy management. General knowledge about the disease, symptoms, treatment, and topics relevant to families' daily lives were evaluated. The contents included educational videos, online forums, and live video chats. A pretest/posttest questionnaire survey was used to evaluate the impact of the program.

Results: A total of 207 participants enrolled in the educational program, which was completed by 130 (62.8\%). Knowledge acquisition improved significantly following participation in the program in 15 out of 30 items (50\%), reaching $P<.001$ for 8 items (26.7\%). Of the 207 participants who started the program, $139(67.1 \%)$ visited online forums, and $27.5 \%$ attended video chats. Average overall satisfaction with the educational program was 8.78 (on a scale of 0 to 10 ).

Conclusions: The results obtained show that parents improved their knowledge in all areas of food allergy. The high level of satisfaction among participants suggests that digital learning tools are effective and motivational, enabling patients to acquire appropriate knowledge and thus increasing their quality of life.
\end{abstract}

Key words: Patient education. eHealth. Patient engagement. Empowerment. Digital health. Food allergy. Anaphylaxis. e-patient. Health education. eLearning.

\section{Resumen}

Introducción: El aumento de la prevalencia de la alergia alimentaria afecta no solo a los pacientes, sino también a sus familias. Objetivo: Evaluar el impacto de un programa educativo online, diseñado para padres y cuidadores de niños con alergia alimentaria. El programa fue desarrollado por un grupo multidisciplinario de profesionales sanitarios, investigadores y pacientes expertos, bajo el modelo de la medicina participativa.

Material y métodos: Los participantes tomaron parte en un programa educativo online de dos semanas que cubría los principales temas relacionados con la alergia a alimentos. Se evaluó el conocimiento general acerca de la enfermedad y aspectos relevantes para la vida diaria de la familia. Los contenidos incluyeron: videos educativos, foros online y videoconferencias en directo. Para evaluar el impacto del programa se utilizó un cuestionario pre y post-intervención.

Resultados: Un total de 207 participantes se inscribieron en el programa. De éstos 130 (62,8\%) lo completaron. En 15 (50\%) de los 30 aspectos evaluados se observó mejoría en el conocimiento previo, alcanzando una significación de <0,001 en 8 ítems (26,7\%). De los 207 participantes que iniciaron el programa, $139(67,1 \%)$ visitaron los foros online y 27,5\% asistieron a las videoconferencias. La satisfacción media con el programa fue de 8,78 (escala 0 a 10).

Conclusión: Los resultados demuestran la mejoría del conocimiento de los padres en los temas incluidos en el programa. La alta satisfacción obtenida sugiere que las herramientas de aprendizaje digital son eficaces y motivadoras para adquirir conocimientos y habilidades que permitan mejorar la calidad de vida.

Palabras clave: Educación a pacientes. Empoderamiento. Salud digital. Alergia alimentaria. Anafilaxia. Educación en salud. eLearning. 


\section{Introduction}

The prevalence of food allergy is increasing [1], with approximately $4 \%-8 \%$ of the pediatric population now affected by this condition [2-4]. It is known that the parents of a child with food allergy have a poorer perception of their family's general health than the parents in the general population [5].

Major actors in health care, including the World Health Organization and other large agencies, are increasingly advocating a more proactive role of patients and their caregivers. This approach, known as patient empowerment, is already a powerful reality that is made possible through advances in technology. Health care organizations and professionals cannot be excluded from this new framework [6].

Within this context, the present study aims to demonstrate the benefits of patient and family education in food allergy using digital tools. These tools impart not only theoretical knowledge, but also practical information that can make everyday life easier for patients and caregivers.

A multidisciplinary group of health care professionals, researchers, and expert patients was created with the goal of developing a research project that would enable us to evaluate the impact of an educational program aimed at parents and caregivers of children with food allergy. This program was run in 2 modalities: online and in-person [7]. The present article analyzes the results of the online program.

\section{Materials and Methods}

The project is based on an educational program for food allergy known as CESA (Conocer, Evitar, Síntomas, Actuar [Know, Avoid, Symptoms, and Administer epinephrine]).

The project team consisted of researchers, nurses, allergists, and expert parents of patients (parents of allergic children) who were members of the main Spanish food allergy patient associations (AEPNAA, Immunitas Vera, and Elikalte).

\section{Study Tool}

An online educational platform was built based on Moodle, a free and open-source learning management software [8].

\section{Educational Materials}

Three units comprising educational videos were created (Table 1). The first focused on imparting general knowledge about food allergy and its symptoms and management. The second unit covered allergen avoidance, the most common allergenic foods, labelling, cooking, shopping, and relationships with health care professionals and at school. The third unit consisted of 2 video classes: one teaching practical skills for proper use of an epinephrine autoinjector and another where mothers of children with food allergy discussed their personal experiences of various topics.

Online discussion forums moderated by physicians and expert patients within the platform were always available. We also ran 3 streaming video chats, 1 with an allergist and the other 2 led by expert patients. The video classes were each 1 hour and 45 minutes long. Each streaming video was 1 hour long.
Table 1. Educational Materials: Content

\begin{tabular}{|c|c|}
\hline Evaluation & Prequestionnaire \\
\hline \multirow[t]{4}{*}{ Unit 1 (31 min) } & General disease contents \\
\hline & What is food allergy? \\
\hline & Symptoms \\
\hline & Treatment \\
\hline \multirow[t]{2}{*}{ Streaming $1(1 \mathrm{~h})$} & Streaming video chat \\
\hline & Allergist \\
\hline \multirow[t]{6}{*}{ Unit 2 (53 min) } & Daily life management \\
\hline & How to avoid allergens \\
\hline & Most common allergenic foods \\
\hline & Regulations and labelling \\
\hline & $\begin{array}{l}\text { Balanced nutrition. Eating safely. } \\
\text { Kitchen management. }\end{array}$ \\
\hline & $\begin{array}{l}\text { Living with allergies in the family and } \\
\text { school and relationships with health } \\
\text { care professionals. }\end{array}$ \\
\hline \multirow[t]{2}{*}{ Streaming $2(1 \mathrm{~h})$} & Streaming video chat \\
\hline & Expert patient: labelling and cooking \\
\hline \multirow[t]{3}{*}{ Unit 3 (19 min) } & $\begin{array}{l}\text { Practical skills and personal } \\
\text { experiences }\end{array}$ \\
\hline & $\begin{array}{l}\text { Using properly the epinephrine } \\
\text { autoinjector properly. }\end{array}$ \\
\hline & Personal experience of mothers \\
\hline \multirow[t]{2}{*}{ Streaming $3(1 \mathrm{~h})$} & Streaming video chat \\
\hline & $\begin{array}{l}\text { Expert patient: relationships in school } \\
\text { and with doctors }\end{array}$ \\
\hline Evaluation & Postquestionnaire \\
\hline
\end{tabular}

\section{Study Population}

Participants had to register online and complete a precourse questionnaire. We opened the online form in October 2012, 4 months before the educational program went live (February 2013). The program was distributed through the patient associations involved in the study, which advertised it by mail and through their Facebook profiles.

Overall, 277 individuals from most cities in Spain preregistered for the program. Madrid (23.8\%) and Barcelona $(16.6 \%)$ were most represented cities in the sample. When the program began, 207 of the preregistered individuals (74.7\%) enrolled to become participants. Of these, $130(62.8 \%)$ completed the educational program and filled out the final postcourse questionnaire.

\section{Intervention}

Program content was divided into 3 units, each covering different topics: general clinical aspects, daily life management, and practical skills and parents' personal experiences (Table 1).

The online program remained open for 2 weeks, during which time users were able to log in and follow the classes at any time. The contents could be revisited at will. The full 
online program lasted approximately 5 hours. A special forum section moderated by doctors and expert patients was opened for comments and questions. Three live video chats were streamed, 1 led by an allergist and covering clinical topics and 2 led by expert patients. These videos were recorded and made available in the platform for participants who had been unable to take part during the live stream.

The users' activities and experiences with the online platform, as well as completion and collection of the questionnaires, were monitored through a unique code assigned to each user.

\section{Evaluation: Trial Design}

Given the lack of instruments developed specifically for this purpose, a pretest/posttest evaluation was carried out via an ad hoc questionnaire created for the program and based on a literature review and on the opinions of experts in allergy and education. The questionnaire comprised 40 items designed to evaluate both knowledge about food allergies and the impact of the online learning program. All of the items were explained in detail in the educational materials. The same questionnaire was distributed at the beginning and the end of the course, enabling the results to be analyzed before and after.

Among the 40 questionnaire items, 18 covered general knowledge of food allergy (6 items), symptoms (6 items), diagnosis ( 3 items), and treatment ( 3 items). The remaining 22 items concerned parents' daily lives, with questions about labelling (8 items), cooking (9 items), school (2 items), and latex and medicines (3 items).

A 5-item Likert-scale inventory, ranging from 'not at all' to 'a great deal', was used to assess satisfaction with the educational program. A space for free-text comments was also included.

The statistical analysis was descriptive. For the data analysis, preprogram and postprogram questionnaire answers were compared using SPSS. McNemar's test was used to detect statistically significant differences in the proportions of correct and incorrect answers between the pretest and posttest period. Statistical significance was set at $P<.05$.

\section{Ethics}

The research project met all methodological requirements and was approved by the Research Ethics Committee of La Paz University Hospital, Madrid, Spain. The project also received joint approval from scientific societies involved in the treatment of this condition, namely, the Spanish Allergy Society (SEAIC, http://www.seaic.org/), the Society for Clinical Paediatric Allergology and Immunology (SEICAP, http://www.seicap.es/), and the Spanish Association of Pediatrics (AEP, http://www.aeped.es/).

All patients gave their written informed consent to participate in the study.

\section{Results}

The sample comprised 207 participants. Of these, 130 $(62.8 \%)$ completed the educational program and filled in the final postcourse questionnaire.
The participants in the study included 98 mothers (75.4\%), 19 fathers $(14.6 \%)$, and 13 caregivers $(10.0 \%)$. The families included comprised 85 boys (65.4\%) and 45 girls (34.6\%) with food allergies and an average age of 5.46 (3.5) years.

The products most frequently responsible for reactions were eggs (56\%), milk (53\%), nuts (48\%), fruits (24\%), fish $(14 \%)$, shellfish $(9 \%)$, legumes $(12 \%)$, latex $(1 \%)$, and other foods $(19 \%)$. These findings are consistent with those for the most common allergenic foods affecting children in Spain [9].

As for previous educational experience, 79 participants $(60.8 \%)$ stated that they had received sufficient training on food allergy management. Their main sources of information were Internet searches and forums (62\%), patient associations $(59 \%)$, health care professionals (physicians and nurses) $(52 \%)$, books and other written materials (40\%), and other sources $(4 \%)$. Using the prequestionnaire, we identified 10 items for which 125 or more of the 130 program completers (96\%) already knew the correct answers before starting the online program. Accordingly, these 10 items were not evaluated.

Evaluation of knowledge acquisition by the participants who completed both the preprogram and postprogram online course questionnaires revealed a significant improvement in 15 of the 30 items analyzed (50.0\%), with $P<.001$ for 8 items $(26.7 \%)$ (Table 2). In the first part of the program (general and clinical aspects of food allergy), parents improved in 7 out of 12 items $(58.3 \%)$, with 3 items $(25.0 \%)$ reaching $P<.001$; in the second part of the program, an improvement was recorded in 8 items out of $18(44.4 \%)$, with 5 items (27.8\%) reaching $P<.001$ (Table 2).

Parents' knowledge of 5 of the items $(41.7 \%)$ related to general and clinical aspects of food allergy and of 10 of the items $(55.6 \%)$ related to daily life management did not improve.

A 5-item Likert-scale inventory (ranging from 'not at all' to 'a great deal') was used to evaluate participant satisfaction

Table 2. Summary of Results

\begin{tabular}{lcccc}
\hline $\begin{array}{c}\text { Total } \\
\text { Items } \\
\text { Evaluated }\end{array}$ & $\begin{array}{c}\text { Total } \\
\text { Items } \\
\text { Improved }\end{array}$ & $\begin{array}{c}\text { Total } \\
\text { Items not } \\
\text { Improved }\end{array}$ & $\begin{array}{c}\text { Items } \\
\text { Improved } \\
\text { With }<.001\end{array}$ \\
\hline General knowledge and clinical aspects & & \\
\hline General knowledge & 3 & 2 & 1 & 1 \\
Symptoms & 4 & 2 & 2 & 1 \\
Diagnosis & 3 & 1 & 2 & 0 \\
Treatment & 2 & 2 & 0 & 1 \\
Subtotal & 12 & 7 & 5 & 3 \\
\hline Daily life with food allergy & 6 & 3 & 3 & 2 \\
\hline Labelling & 8 & 4 & 4 & 2 \\
Cooking & 2 & 1 & 1 & 1 \\
School & 18 & 8 & 10 & 5 \\
\hline Latex and medicines & 2 & 0 & 2 & 0 \\
\hline Subtotal & & & & 8 \\
\hline Total & 30 & 15 & 15 & 8 \\
\hline Total & & & & \\
\hline
\end{tabular}


with the program. We asked 3 questions regarding general improvement in knowledge, avoidance of allergic foods, and identification of symptoms. A final question designed to evaluate overall satisfaction with the program was also included. Again, space for free-text comments was provided.

Most parents and caregivers $(83.1 \%)$ gave their improvement in general knowledge about food allergy a rating of 7 or higher (mean, 7.76) on a scale of 1 to 10 (in which 0 $=$ 'not satisfied' and $10=$ 'very satisfied'). As for knowledge of how to avoid allergenic foods, $70 \%$ of the participants assigned their knowledge a score of 7 or higher (mean, 7.27). In the section on how to better recognize children's symptoms, $84.6 \%$ of participants scored their knowledge with 7 or higher (mean, 8.2).

Overall satisfaction with the educational program received an average rating of 8.78 ; in particular, $83.1 \%$ of participants gave the course a score of 8 to 10 points, and $44.6 \%$ gave it 10 points.

\section{Online Platform Experience and Usability}

Of the 207 participants who started the program, 139 $(67.1 \%)$ visited the online forums: $106(76.2 \%)$ visited the forums up to 25 times, and $33(23.8 \%)$ more than 26 times during the 2 weeks of the program. Of the 139 forum visitors, $85(61.1 \%)$ posted messages: $60(70.6 \%)$ posted 1 to 4 messages, $22(25.9 \%)$ posted more than 5 messages, and $3(3.5 \%)$ contributed by opening a new discussion topic (Figure).

The live video chat led by a physician (allergist) was watched by 57 participants $(27.5 \%)$, while the second and third live video chats, each led by an expert patient, were attended by $38(18.3 \%)$ and $33(15.9 \%)$ participants, respectively (Figure).

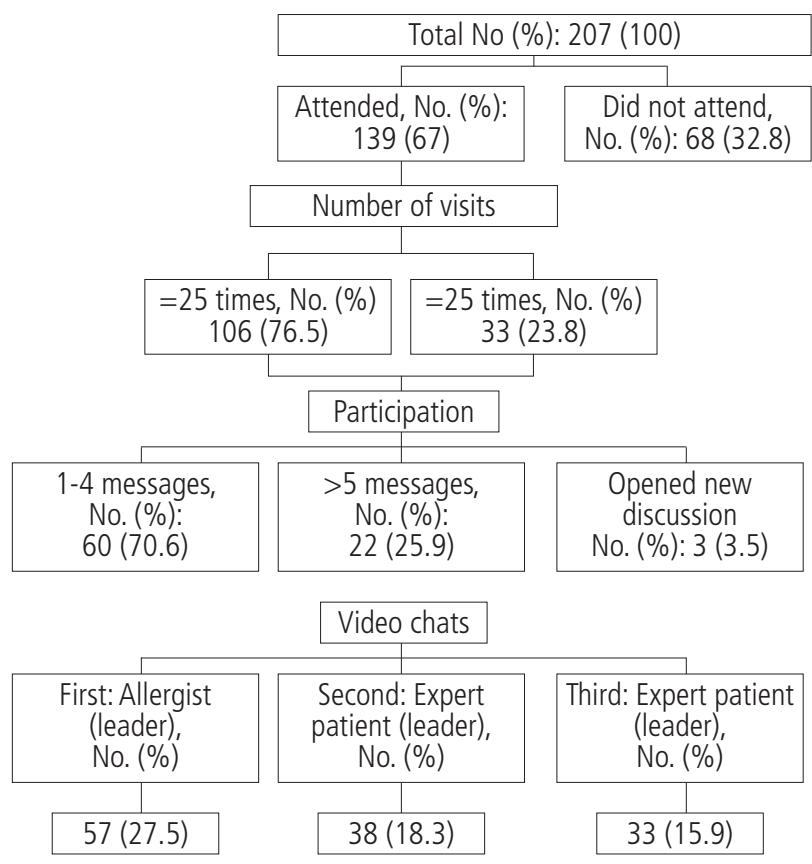

Figure. Online platform experience and usability.

\section{Discussion}

The responsibility of health professionals does not end with the diagnosis of a condition, but includes guidance and education for patients and their families. In food allergy, education remains an essential factor for improving patients' quality of life. A more holistic approach is needed, including training in and management of comorbidity [10]. Even though school-aged children are capable of acquiring skills that allow them to self-manage their condition, parents still play a fundamental role in education and are responsible for their well-being until they come of age [11].

Our goal was to evaluate the impact of an online educational program for parents of children with food allergy. We also showed the benefits of participatory medicine, a paradigm in which doctors and patient organizations work together, enabling greater trust and enhanced impact on patient engagement.

The correspondence between allergy triggers and the most prevalent childhood food allergies in Spain (eggs, milk, and nuts) [9] indicates that our sample was representative of the general population.

Most of the participants in this study were members of patient organizations. It is important to note that 79 participants $(60.8 \%)$ initially indicated that they had sufficient knowledge about food allergies. Upon conducting our first statistical analysis of the study population (130 participants), we identified 10 questionnaire items for which 125 or more participants ( $96 \%$ of the study population) already knew the correct answers before they had even started the online program. This demonstrates that patients were aware, informed, and took responsibility for their care. Prior knowledge was more robust for clinical and general matters of food allergy than for daily management of the condition.

The results obtained show us that parents' knowledge of food allergy increased, with an improvement reported in 15 out of 30 questionnaire items (50\%) and a highly significant improvement $(P<.001)$ in 8 items $(26.7 \%)$. Improvement was more frequent in the general and clinical aspects domain ( 7 items out of $12,58.3 \%$ ) than in the daily life domain ( 8 items out of $18,44.4 \%$ ).

Food allergy affects the routines and daily life of patients and their families in myriad aspects, from cooking and shopping to managing the social relationships of children at school. It is a disease that requires thinking beyond the usual methods recommended during regular visits to allergy outpatient clinics, because most patients do not follow the recommendations (especially with respect to the epinephrine autoinjector) [10-12]. Our outcomes show that information about daily life is not easy to understand, and that additional efforts in education and skill building are needed to help patients, parents, and caregivers.

Parent participation in the community of the program was high, indicating considerable interest in sharing experiences and finding answers to their questions. The program had a positive impact on participants' knowledge, motivating them to participate in the community. Participants reported a high overall level of satisfaction with the program, with an average score of 8.78 out of 10 , and $44.6 \%$ of parents giving the program a full score of 10 . 


\section{Limitations}

Our study is limited by the fact that the sample was recruited from patient associations; therefore, participants were likely to be more knowledgeable about food allergy than the general population. Furthermore, this research aims to evaluate the improvement in the knowledge and satisfaction of the participants; we did not evaluate the improvement in symptoms or quality of life because there is currently no validated questionnaire in Spanish for this purpose.

\section{Implications for Clinical Practice and Further Research}

The results obtained confirm that the online educational program improved parents' and caregivers' knowledge in many areas of food allergy, even though their background knowledge was already very good.

Education through new technologies is improving by the day, because it helps shorten distances at greater speed, and thus allows educators to reach more people [13].

New research focusing on parents whose children have recently been diagnosed can show the medical community that we can help and guide patients through user-friendly technology and joint efforts.

\section{Acknowledgments}

We thank the boards of directors of the patient associations and their volunteers, as well as the expert parents of patients and the physicians who participated in the workshops.

The authors would like to acknowledge the parent members of patient associations and the professionals who voluntarily participated in the development of the workshops. Without their hard work and enthusiasm, this research would not have been possible.

\section{Funding}

The research was funded by MEDA Pharma.

\section{Conflicts of Interest}

The authors declare that they have no conflicts of interest.

\section{References}

1. Branum AM, Lukacs SL. Food Allergy Among Children in the United States. Pediatrics 2009;124;1549-55.

2. Boyce JA, Assa'ad A, Burks AW, Jones S, Sampson H, Wood R, et al. Guidelines for the Diagnosis and Management of Food Allergy in the United States: Report of the NIAID-Sponsored Expert Panel. J Allergy Clin Immunol. 2010;126:51-8.
3. Dyer A, Gupta R. Epidemiology of Childhood Food Allergy. Pediatr Ann. 2013;42:101-5.

4. Muraro A, Werfel T, Hoffmann-Sommergruber K, Roberts $G$, Beyer K, Bindslev-Jensen C, et al. EAACl Food Allergy and Anaphylaxis Guidelines. Diagnosis and management of food allergy. Allergy. 2014;69:1008-25.

5. Sicherer SH, Noone SA, Muñoz-Furlong A. The impact of childhood food allergy on quality of life. Ann Allergy Asthma and immunol. 2001;87:461-4.

6. Traver Salcedo V. El ePaciente y las redes sociales. Publidisa; [cited 2016 Oct 24]. Available from: https://ec.europa.eu/ eip/ageing/sites/eipaha/files/results_attachments/ libro_el_ epaciente_y_las_redes_sociales.pdf.

7. Contreras-Porta J, Ruiz-Baqués A, Gabarron Hortal E, Capel Torres F, Ariño Pla MN, Zorrozua Santisteban A, et al. Evaluation of an educational program with workshops for families of children with food allergies. Allergol Immunopathol (Madr). 2016;44:113-9.

8. Moodle - Open-source learning platform | Moodle.org [Internet]. Available from: https:// moodle.org/?lang=es.

9. Fernández Rivas M. Food Allergy in Alergológica-2005. J Investig Allergol Clin Immunol. 2009;19:37-44.

10. Nieto-Nieto A, Tejedor-Alonso MA, Farias-Aquino $E$, et al. Clinical Profile of Patients With Severe Anaphylaxis Hospitalized in the Spanish Hospital System: 1997-2011. J Investig Allergol Clin Immunol. 2017;27:111-26.

11. Vale S, Smith J, Said M, Mullins RJ, Loh R. ASCIA guidelines for prevention of anaphylaxis in schools, pre-schools and childcare: 2015 update. J Paediatr Child Health. 2015;51:94954.

12. Múgica-García MV, Tejedor-Alonso MA, Moro-Moro $M$, Esteban-Hernández J, Rojas-Perez-Ezquerra PE, Vila-Albelda C, et al. Self-Management of Anaphylaxis is Not Optimal. J Investig Allergol Clin Immunol. 2015;25:408-15.

13. Shah D. Online education: should we take it seriously? Climacteric. 2016;19:3-6.

| Manuscript received April 28, 2017; accepted for publication November 15, 2017.

\section{- Armando Ruiz Baqués}

Pasaje del Amor, ${ }^{\circ} 1$ Bajos primera

Santa Margarida de Montbui

08710 Barcelona, Spain

E-mail: armandoruizb@gmail.com 